\title{
The Impact of Investor Sentiment on IPO Underpricing
}

\author{
Beiyi Chen ${ }^{1 *} \dagger$, Jingyi Liu $^{\dagger 2}$, Borui Zhu ${ }^{\dagger 3}$ \\ ${ }^{1}$ Wenzhou Business College Wenzhou, Zhejiang, China, *chenbeiyi123@foxmail.com \\ ${ }^{2}$ Central University of Finance and Economics Beijing, China, 2018311788@email.cufe.edu.cn \\ ${ }^{3}$ Minzu University of China Beijing, China, 18011434@muc.edu.cn \\ These authors contributed equally.
}

\begin{abstract}
Investor sentiment is the belief formed by investors based on the expectation of future cash flow of assets and investment risk, which will affect investors' trading behavior to a certain extent. In recent years, more and more scholars have done a lot of research on IPO underpricing from the perspective of investor sentiment. It is found that investor sentiment has a certain effect on the IPO market. Taking 2,955 A-share listed stocks from 2003 to 2020 as samples, this paper uses an econometric regression model to conduct the empirical test, investigates the relationship between investor sentiment and IPO underpricing, and explores the mechanism. The results show that: (1) Investor sentiment has a significant promoting effect on IPO underpricing. Positive investor sentiment will affect the demand for new shares, promoting IPO underpricing. (2) Investor sentiment affects IPO underpricing by affecting the market turnover rate. On the first day of listing, the turnover rate plays a partial intermediary role in the path of investor sentiment affecting IPO underpricing. (3) The effect of investor sentiment on underpricing stocks with lower issue prices is less than that of stocks with higher issue prices.
\end{abstract}

Keywords-investor sentiment, IPO underpricing, the turnover rate.

\section{INTRODUCTION}

\subsection{Literature review}

IPO is when a company sells its shares to the public for the first time. IPO underpricing refers to the phenomenon that the initial public offering price is significantly lower than the initial market price. The famous American scholar Jerita found that from 1980 to 2001, the closing price of more than 6000 IPOs in the United States was 20\% faster than the offering price. The market's annual return in the same period was maintained at about $7 \%$ to $8 \%$. In 1986, Rock began to use the winner's curse hypothesis to explain the IPO pricing phenomenon. He believed that IPO underpricing gives investors with inferior information certain risk compensation. However, with the continuous improvement of market openness and transparency and the improvement of relevant systems, the IPO premium does not show a weakening trend. In the 1990s, Ivy Voss, a scholar from Yale University, put forward the information waterfall theory, emphasizing that the information asymmetry between investors and companies would lead to IPO underpricing. However, with the deepening of the institutionalization and specialization of global market investment, the herd effect did not weaken significantly.

In recent years, with the further development of behavioral finance, some foreign scholars have done a lot of research on IPO premium from the perspective of investor sentiment. Yunlong Duan, Shuaijie Wang, and Weiwei Yang [1] measured the influence of investor sentiment from the perspective of long-term performance and believed that reducing the excess return on the first day of IPO could improve the long-term allocation efficiency of the capital market. However, reflecting investor sentiment from the perspective of WeChat text mining could not fully reflect the sentiment of nonWeChat users. According to the research of Japanese scholars Che-Yahya, Norliza and Matsuura, Yoshiyuki [2], higher initial return and trading volume are expected in IPOS with higher investors' optimism in the Japanese market. Still, it's worth exploring whether there is a similar situation in the Chinese market. Shengwen Pan and 
Chuandong $\mathrm{Wu}$ [3], from the perspective of the system, believed that the system of the limit of rising and fall would make investors' sentiment higher, and both of them increased the degree of IPO premium at the same time. However, in the later IPO process of the science and innovation version (the first five trading days did not limit the rise and fall), there was still an obvious IPO underpricing phenomenon. Indian scholars Singla and Harish Kumar [4] focused on the impact of investor sentiment on the IPO price of the Indian stock market and distinguished the construction and non-construction sectors. Cook et al. and Shao [5] et al. both found that IPO companies would actively use mainstream media for information disclosure during listing to achieve an ideal underpricing level. But due to the different degrees of acceptance of mainstream media by different investors or industries, the underpricing of IPO will vary greatly. Tinic believes that investors' speculative psychology causes the high IPO premium rate. When new shares are issued, the "herd effect" makes investors chase after each other. And the demand for stocks is far greater than the supply, which pushes up the transaction price, making the price deviate from the real value and distorting the market pricing mechanism, forming IPO premium. Long, Shleifer, and Summers put forward the investor sentiment theory. They believed that noisy investors were easily affected by their own emotions, and their trading behaviors would be biased and irrational. When too many noisy traders entered the secondary market, the trading price would deviate from the normal track, and excessive demand would lead to IPO underpricing. Aggarwal and Rivoli also believed that the main IP premium source is noise traders, and it is not intentional by issuers. Due to the excessive reaction of the secondary market to the issuance of new shares, the first-day listing price is higher than the real price of the stock. However, as time goes by, investors' expectations for the stock return to normal, the stock price returns to the real value, and the bubble will also burst.

On the market level, Chen Yangyang [6] explored the performance of IPO stock prices in the secondary market under the special event of terrorist attack and found that the event indirectly led to reduced IPO underpricing caused by investor sentiment fluctuations. Boulton and Thomas J. et al. [7] found that in markets where short selling is allowed, mortgage loans are allowed. And short selling is usually practiced, non-positive returns on the first day of listing are more likely to occur. They concluded that short-selling restrictions have intensified the positive relationship between investor sentiment and underpricing. Ren Hui and Sun Qian studied 355 companies listed on the GEM during 2009-2013 [8], also concluded that investor sentiment was significantly positively correlated with IPO underpricing. That is, in the GEM of China, investors' speculative behavior and blind following phenomenon led to the overheating of new shares, high investor sentiment and excessive IPO underpricing. Therefore, from the perspective of private enterprises listed on GEM in China, this paper takes a total of 2,955 A-share listed stocks from 2003 to 2020 as samples to empirically study the relationship between investor sentiment and IPO underpricing and explore the mechanism.

\subsection{Hypothesis development}

Traditional finance is based on the entire rationality of investors, while the theory of behavioral finance is based on the bounded rationality of investors. In recent years, the concept of investor sentiment based on behavioral finance has been gradually used by scholars to modeling or proving in practice. Cornelli, Goldreich, and Ljunqvist [9] used mathematical models to study the gray trading market in Europe and found that investor sentiment can significantly affect investors' demand for new shares and greatly influence the new share issuance market.

In the Chinese securities market, according to a report issued by Tencent Securities at the beginning of 2021: As of October 2020, a total of 14.87 million domestic stock investors have been added this year, and retail investors are still the mainstream of the A-shares market. In comparison, the number of natural person investors accounted for $99.78 \%$ of the total number of A-shares market, a new high in the past five years. In terms of capital, after excluding the unique, large, and rarely traded legal shares in the Chinese securities market, the proportion of outstanding shares held by retail investors is as high as $67.5 \%$, which shows the important position and huge base of retail investors in the Chinese security secondary market.

However, there is a noteworthiness that accounts with a capital of less than RMB 500,000 in the Chinese securities market account for as much as $87.3 \%$. The small amount of funds makes retail investors tend to invest in the short-term, and they want to get more benefits quickly through aggressive and frequent transactions. These investors will overestimate the expected return of the enterprise and underestimate the investment risk, resulting in more radical and irrational investment behavior. What's more noteworthy is that retail investors in China are very keen on trading. According to the Shanghai Stock Exchange's annual report, $85 \%$ of daily transactions on the Shanghai Stock Exchange come from retail investors, and only about $10 \%$ come from institutional investors. The annual trading volume of retail investors is more than $800 \%$ of that of institutional investors. According to relevant psychology theories, investors often have a kind of overconfidence in their investment behavior, believing that they have made correct decisions after having certain information and rational thinking, so they frequently trade stocks. But in fact, over-trading caused by overconfidence is often affected by one's own emotions.

In a large number of retail investors, there are still cases of less information and information asymmetry. 
There are stock forums and various social media group chats on the Internet in China, which makes single retail investors inevitably affected by the behavior of outside groups. Especially in the case of inadequate access to information, the retail investors will be driven by emotions and exhibit a "herding effect" that tends to be the same as other investors' trading behaviors. Therefore, "emotions" will become an important part of retail investors' investment decisions. Emotion-led investors will influence the opening, closing price, or daily limit of the IPO day through more irrational behaviors, resulting in IPO underpricing.

Due to the existence of short-selling restrictions of the Chinese securities market, negative investors are unwilling to participate in stock trading. Irrational trading behavior in the market will decrease, and the impact of rational factors on stock prices will rise or even become dominant. In that time, investor sentiment will not affect IPO underpricing.

At the same time, Yixia Wang pointed out that investors with cognitive bias and information asymmetry will overreact to optimistic information but underreact to pessimistic information. Investors with negative emotions will watch in silence [12]. Wen Fenghua and others also concluded that negative sentiment has no significant impact on stock returns [13]. Especially under the continuous high upsurge of "Initial Public Offerings" in the Chinese financial market and the strong speculative atmosphere, investors will resist the effect of negative sentiment and thus have no significant impact on IPO underpricing. Based on the above statement, hypothesis 1 is proposed as follows.

Hypothesis 1: Investor sentiment has a positive correlation to IPO underpricing of listed companies. That is, as investor sentiment increases, the extent of IPO underpricing of listed companies becomes higher.

The turnover rate on the first day of listing refers to the frequency of stocks changing hands on the day of listing, that is, the ratio of the trading volume on the first day to the total number of shares outstanding. It is one of the important indicators reflecting the stock's liquidity, and it also reflects the degree of market activity. And it is also one of the most important technical indicators that reflect the activity level of the market.

The high turnover rate of new stocks on the first day of listing in the Chinese A-share market is a relatively common phenomenon. The high turnover rate indicates the frequent flow of stocks, and investors have shown great concern about stocks.

On the day of the new stock listing, if investors expect that the stock price will continue to rise in the future and the yield will continue to increase, they will not easily sell the stocks they hold, which leads to a low rate of new stock turnover. If the price is expected to fall in the future, to stop the loss in time, a large number of shares will be sold, and the overturn rate of new shares will be high. Stocks with a high turnover rate have relatively strong liquidity. Baker and Stein [14] believed that, The turnover rate can reflect the liquidity of stocks. In a market where short selling is restricted, the increase in investor demand accelerates the flow of a certain stock. Therefore, the turnover rate can be used as a measure of investor sentiment. When Baker and Wurgler [15] construct investor sentiment indicators to study the impact of this variable on stock returns, the turnover rate is used. This article chooses the turnover rate as a measure of investor sentiment. The higher the turnover rate, the greater the frequency of new stock transactions and the higher the investor sentiment. Rajan and Servaes [16] used. The firstday price-earnings ratio measures investor sentiment and proves that the higher the ratio, the higher the investor sentiment.

As mentioned in the previous article, retail investors in China pay more attention to short-term trading and are highly speculative. The stock prices of the companies they invest in fluctuate sharply, and investment risks are relatively high. The main factors affecting the turnover rate in China are the following settlement period and investor structure. Stocks with short settlement periods have more frequent transfers and a higher turnover rate. The turnover rate of the securities market dominated by retail investors is relatively higher than that of the securities market dominated by institutional investors such as funds. Generally speaking, the more popular stocks are, the higher people's desire to buy. The higher the stock trading activity, the higher the turnover rate, and the more obvious the phenomenon of IPO underpricing. Based on this, hypothesis 2 is proposed as follows:

Hypothesis 2: The turnover rate on the first day of the listing is positively correlated with IPO underpricing.

Although IPO underpricing is common in the actual stock market, the underpricing ratio of each stock is different. In general, when facing high-priced stocks, retail investors have psychological concerns. Firstly, it seems easy for low-priced stocks to double from 2 yuan to 4 yuan, and the investors even think it can be higher. This is "price temptation" or "price trap". High-priced stocks give the illusion that the upside is very limited. Secondly, retail investors like to buy low-priced stocks because of a fear of high prices. The Chinese stock market has always been short-bullish and long-bearish. In most people's view, high-priced stocks are always suspected of overdrawing their future growth. The concern of retail investors is that after buying high-priced stocks, it is easy to lose if there is a sharp readjust. For example, the opening price of PetroChina Company Limited (A-share code:601857) was 16 yuan after it went public that year, and the highest that day rose to 48 yuan. Now PetroChina has continued to fall and is hovering at 4 yuan. High stock prices give people a deep impression of fear. Thirdly, high-priced stocks have a lot of room to fall, but low-priced stocks 
seem to be infallible. Low-priced stocks have limited downside and large upside. And they are often the first defensive sector for senior retail investors in a bear market.

A large number of retail investors buy stocks with lower prices, resulting in increased volatility of low-priced stocks affected by investor sentiment. The dynamics in the market will inspire emotions that will make investors' mood changes from conforming to the dynamics. And it will present in turnover rates and prices.

In summary, hypothesis 3 is proposed as follows:

Hypothesis 3: Investor sentiment in stocks with lower issue prices has less promotion of underpricing than highpriced stocks.

\section{STUDY DESIGN}

\subsection{Econometric model}

This paper studies the impact of investor sentiment on IPO underpricing and establishes a regression model with investor sentiment as the explanatory variable, IPO underpricing rate as the explanatory variable. In this paper, the index constructed comprehensively is used as a proxy variable of investor sentiment. The comprehensive index of investor sentiment CICSI and ISI is constructed using the principal component method based on the past securities trading data and the investor information index CCI, reflecting investor sentiment. The empirical model takes logarithm treatment for the IPO underpricing rate, investor sentiment index, and control variables to reduce the heteroscedasticity of the equation and the multicollinearity of the variables. To reduce the impact of the omitted variables on the regression results and increase the stability of the model, we also introduced the issue size, issue interval, and issue price as the control variables. To reduce the impact of the omitted variables on the regression results and increase the stability of the model, this paper also introduced the issue size, issue interval, and issue price as the control variables. It established the regression model as follows: The regression model is established as follows:

$$
\begin{aligned}
& U P_{i}=\alpha+\beta_{1} \text { CICSI }_{i}+\beta_{2} I N D U S T R Y_{i}+\beta_{3} L A G_{i}+ \\
& \beta_{4} A G E+\beta_{8} I_{S S U E P R I C E}+\varepsilon
\end{aligned}
$$

Where $\mathrm{i}$ is the individual stock, $\alpha$ is the constant term, $\beta \_i$ is the correlation coefficient of each variable, and $\varepsilon$ is the residual term. Model (1) takes investor sentiment as the core explanatory variable and IPO underpricing rate as the explained variable, focusing on studying the impact of investor sentiment on the IPO underpricing rate.

\subsection{Variable selection and definition}

In this paper, the 2,955 A-share listed stocks from 2003 to 2020 were taken as samples, and the collected samples were sorted out, and outliers and missing values were removed. The investor sentiment index, basic data, and control variables are all from the CSMAR database.

\subsubsection{IPO Underpricing Rate (UP)}

IPO underpricing is the core explanatory variable in this paper, which refers to the issue price of shares in the initial offering of an enterprise is significantly lower than the closing price. The underpricing rate is expressed as

$$
U P=\frac{\text { First day closing price of new shares }- \text { IP0 price }}{\text { IP0 price }}
$$

\subsubsection{Investor sentiment}

Investor sentiment is the belief formed by investors based on the expectation of future cash flow of assets and investment risk. This paper uses the existing research for reference and chooses the comprehensive index CICSI, which can better measure the investment sentiment of the stock market to express investor sentiment. At the same time, this paper also chooses investor sentiment index ISI, consumer confidence index $\mathrm{CCI}$ and the turnover rate on the first day of listing as proxy variables of investor sentiment to support the empirical results.

\subsubsection{Control variables}

This paper takes 2,955 initial issued stocks in A stock market as the research object and tests the relationship between investor sentiment and IPO underpricing through a multiple regression model. Therefore, the selection of control variables should meet the impact on investor sentiment and IPO underpricing at the same time. Referring to Pan Shengwen and Wu Chuandong [3], this paper selected lag, age of the company, price/earnings ratio $(\mathrm{PB})$, price/book ratio $(\mathrm{PB})$, the quantity of new issues and issueprice as the control variables, and also controlled the industry in which the stocks are located. The definition of variables is shown in Table 1 .

TABLE I. VARIABLE DEFINITION

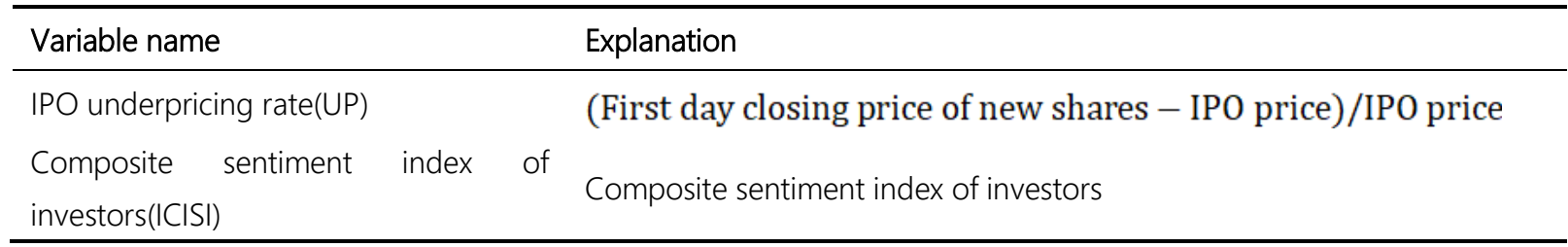




\begin{tabular}{ll}
\hline Investor sentiment(ISI) & Investor sentiment \\
Consumer information index(CIC) & Consumer information index \\
First-day turnover rate(turn) & Trading volume and tradable share capital ratio \\
Industry(industryid) & Industry ID of the first day of issue \\
IPO interval(lag) & The number of days to wait from issue to listing \\
The company age(age) & The number of days since the company was founded \\
P/E ratio(pe) & The P/E ratio at the time of the IPO \\
P/B ratio(pb) & Share price/Net asset value per share \\
Number of new issues(quantity) & The number of shares issued \\
Issuing price(issueprice) & IPO price \\
\hline
\end{tabular}

\subsection{Results}

\subsubsection{The benchmark regression}

Table 2 shows the results of the benchmark regression, and (1) is the OLS regression of investor sentiment and IPO underpricing. It can be seen that investor sentiment has a significant impact on IPO underpricing and shows a positive correlation. To avoid the influence of other variables on the regression results, this paper added control variables into the model and obtained the results that the size and significance of the coefficients in column (2) were not significantly different, proving the robustness of the model from the side. As can be seen from Column (2), investor sentiment has a positive impact on the IPO underpricing rate at the significance level of $5 \%$. The higher the investor's speculative sentiment, the higher the IPO underpricing degree. In addition, this paper also selects investor sentiment ISI index and consumer confidence index as proxy variables of investor sentiment and IPO underpricing rate for regression, both of which have obtained significant positive correlation results.

Investor sentiment refers to investors' belief about the future cash flow and risk of a stock. When investor sentiment is high, it indicates that investors have aboveaverage confidence in their ability to analyze public information and predict stock price movements. Therefore, investors will tend to be optimistic about the IPO stock, thus overestimating the value of the IPO stock. Even the expected price of the IPO stock will be much higher than the issue price. Over-optimistic sentiment leads investors to increase their buying demand for IPO stocks. Therefore, emotionally oriented investors may influence the opening, closing price, or daily limit of IPO through relatively irrational behavior, resulting in IPO underpricing.

TABLE II. BENCHMARK RESULTS

\begin{tabular}{|c|c|c|c|c|}
\hline VARIABLES & $\begin{array}{l}\text { (1) } \\
\text { ln_up }\end{array}$ & $\begin{array}{l}\text { (2) } \\
\text { ln_up }\end{array}$ & $\begin{array}{l}\text { (3) } \\
\text { ln_up }\end{array}$ & $\begin{array}{l}\text { (4) } \\
\text { ln_up }\end{array}$ \\
\hline ln_cicsi & $\begin{array}{l}0.273 * * * \\
(3.18)\end{array}$ & $\begin{array}{l}0.455^{* * * *} \\
(4.07)\end{array}$ & & \\
\hline industryid & & $\begin{array}{l}-0.000 \\
(-0.37)\end{array}$ & $\begin{array}{l}-0.000 \\
(-0.15)\end{array}$ & $\begin{array}{l}-0.000 \\
(-0.43)\end{array}$ \\
\hline ln_isi & & & $\begin{array}{l}0.490 * * * \\
(12.69)\end{array}$ & \\
\hline ln_cci & & & & $\begin{array}{l}1.332 * * * \\
(6.07)\end{array}$ \\
\hline ln_lag & & $\begin{array}{l}0.235 * * * \\
(3.95)\end{array}$ & $\begin{array}{l}0.322 * * * \\
(5.58)\end{array}$ & $\begin{array}{l}0.205 * * * \\
(3.51)\end{array}$ \\
\hline ln_age & & $\begin{array}{l}1.106 * * * \\
(5.63)\end{array}$ & $\begin{array}{l}1.024 * * * \\
(5.54)\end{array}$ & $\begin{array}{l}0.964 * * * \\
(4.89)\end{array}$ \\
\hline quantity & & $\begin{array}{l}-0.159 * * * \\
(-8.63)\end{array}$ & $\begin{array}{l}-0.163 * * * \\
(-9.13)\end{array}$ & $\begin{array}{l}-0.168 * * * \\
(-9.12)\end{array}$ \\
\hline ln_pe & & $\begin{array}{l}0.515 * * * \\
(9.93)\end{array}$ & $\begin{array}{l}0.467 * * * \\
(9.33)\end{array}$ & $\begin{array}{l}0.518 * * * \\
(10.12)\end{array}$ \\
\hline ln_issueprice & & $-0.765 * * *$ & $-0.731 * * *$ & $-0.791 * * *$ \\
\hline
\end{tabular}




\begin{tabular}{lllll} 
& & $(-20.65)$ & $(-21.86)$ & $(-21.48)$ \\
$\ln \_\mathrm{pb}$ & & $0.281^{* * *}$ & $0.276^{* * *}$ & $0.311^{* * *}$ \\
Constant & $(5.65)$ & $(5.88)$ & $(6.26)$ \\
& $-1.785^{* * *}$ & $-3.115^{* * *}$ & $-3.286^{* * *}$ & $-7.119^{* * * *}$ \\
Observations & $(-5.54)$ & $(-4.67)$ & $(-5.51)$ & $(-6.84)$ \\
R-squared & 2,803 & 2,288 & 2,288 & 2,288 \\
\hline
\end{tabular}

Notes: The $\mathrm{t}$-statistic is in parentheses, and the $\mathrm{p}$ value is in square brackets. ${ }^{* *},{ }^{* *}$, and $*$ indicate significance at the 1,5 , and $10 \%$ levels, respectively.

\subsubsection{Mechanism}

According to the theoretical framework in the second part, we speculate that investor sentiment is likely to affect IPO underpricing by influencing the market turnover rate. The turnover ratio is the percentage of the cumulative trading volume of a stock in the total number of tradable shares in a unit of time, which directly reflects the active degree of stock trading. When investors have an optimistic expected price estimate of the IPO stock price, their buying willingness will naturally increase, and the market attention of the stock will be greater. Conversely, when the market ignores a stock, its turnover rate decreases. Thus, the turnover rate, a technical indicator of stock liquidity, is directly affected by investor sentiment. Investors who are optimistic about the future price trend of IPO stock are the main purchasers of the stock. The high turnover rate indicates that the stock has a high number of trading times, and also indicates that the investors' demand for IPO stock increases, which leads to a sharp rise in the stock price on the first day of IPO of the IPO company and intensifies the IPO underpricing level. This paper chooses the turnover rate on the first day of listing as the intermediary variable of investor sentiment affecting IPO underpricing rate to verify this influence path.
Column (1) in Table 3 shows that higher investor sentiment significantly impacts IPO underpricing, which supports H1. This paper verifies the mediating effect of turnover rate on the first day of listing to further study the influence mechanism of investor sentiment on IPO underpricing. In Column (2), the coefficient of investor sentiment on the turnover rate on the first day of the listing is 0.397 , which is significant at the level of $1 \%$, indicating that investor sentiment plays a significant role in improving the turnover rate on the first day of listing. In other words, the higher the investor sentiment is, the higher the stock trading activity will be. (3) Column estimates the relationship between the turnover rate on the first day of listing and the IPO underpricing rate. The coefficient is 0.307 , passing the test at the significance level of $1 \%$, which indicates that a high turnover rate has a significant promoting effect on IPO underpricing rate and is an important factor causing IPO high underpricing. In sub-paragraph (4) in the column of estimated results, listed on the first day of IPO underpricing in coefficient is significant. Still, the effect of investor sentiment on the IPO underpricing rate coefficient from 0.455 to 0.359 , which controls the first-day investor sentiment after the coefficient for IPO underpricing rate is reduced, can be judged on their debut has played a part in the mediation role. It can be inferred that investor sentiment increases IPO underpricing mainly through increasing turnover rate, promoting the intensification of IPO underpricing, and $\mathrm{H} 2$ is verified.

TABLE III. INVESTOR SENTIMENT, TURNOVER RATE AND IPO UNDERPRICING

\begin{tabular}{|c|c|c|c|c|}
\hline VARIABLES & $\begin{array}{l}\text { (1) } \\
\text { ln_up }\end{array}$ & $\begin{array}{l}\text { (2) } \\
\text { ln_turn }\end{array}$ & $\begin{array}{l}\text { (3) } \\
\text { ln_up }\end{array}$ & $\begin{array}{l}\text { (4) } \\
\text { ln_up }\end{array}$ \\
\hline ln_cicsi & $\begin{array}{l}0.455^{* * * *} \\
(4.07)\end{array}$ & $\begin{array}{l}0.397 * * * \\
(6.48)\end{array}$ & & $\begin{array}{l}0.359 * * * \\
(3.24)\end{array}$ \\
\hline ln_turn & & & $\begin{array}{l}0.307 * * * \\
(8.49)\end{array}$ & $\begin{array}{l}0.295^{* * *} \\
(8.12)\end{array}$ \\
\hline industryid & $\begin{array}{l}-0.000 \\
(-0.37)\end{array}$ & $\begin{array}{l}-0.000 \\
(-0.16)\end{array}$ & $\begin{array}{l}-0.000 \\
(-0.33)\end{array}$ & $\begin{array}{l}-0.000 \\
(-0.34)\end{array}$ \\
\hline ln_lag & $\begin{array}{l}0.235 * * * \\
(3.95)\end{array}$ & $\begin{array}{l}-0.034 \\
(-1.06)\end{array}$ & $\begin{array}{l}0.219 * * * \\
(3.78)\end{array}$ & $\begin{array}{l}0.252 * * * \\
(4.29)\end{array}$ \\
\hline ln_age & $\begin{array}{l}1.106 * * * \\
(5.63)\end{array}$ & $\begin{array}{l}-0.248 * * \\
(-2.35)\end{array}$ & $\begin{array}{l}1.337 * * * \\
(7.15)\end{array}$ & $\begin{array}{l}1.168 * * * \\
(6.03)\end{array}$ \\
\hline quantity & $\begin{array}{l}-0.159 * * * \\
(-8.63)\end{array}$ & $\begin{array}{l}0.002 \\
(0.17)\end{array}$ & $\begin{array}{l}-0.159 * * * \\
(-8.74)\end{array}$ & $\begin{array}{l}-0.160 * * * \\
(-8.82)\end{array}$ \\
\hline ln_pe & $\begin{array}{l}0.515^{* * *} \\
(9.93)\end{array}$ & $\begin{array}{l}0.148 * * * \\
(5.32)\end{array}$ & $\begin{array}{l}0.504 * * * \\
(9.92)\end{array}$ & $\begin{array}{l}0.477 * * * \\
(9.29)\end{array}$ \\
\hline ln_issueprice & $\begin{array}{l}-0.765 * * * \\
(-20.65)\end{array}$ & $\begin{array}{l}-0.090 * * * \\
(-4.56)\end{array}$ & $\begin{array}{l}-0.699 * * * \\
(-20.52)\end{array}$ & $\begin{array}{l}-0.743 * * * \\
(-20.29)\end{array}$ \\
\hline ln_pb & $\begin{array}{l}0.281 * * * \\
(5.65)\end{array}$ & $\begin{array}{l}-0.024 \\
(-0.89)\end{array}$ & $\begin{array}{l}0.250 * * * \\
(5.23)\end{array}$ & $\begin{array}{l}0.288 * * * \\
(5.87)\end{array}$ \\
\hline
\end{tabular}




\begin{tabular}{lllll} 
Constant & $-3.115^{* * *}$ & $-2.603 * * *$ & $-1.495^{* *}$ & $-2.417 * * *$ \\
& $(-4.67)$ & $(-7.12)$ & $(-2.49)$ & $(-3.64)$ \\
Observations & 2,288 & 2,435 & 2,288 & 2,288 \\
R-squared & 0.282 & 0.046 & 0.299 & 0.303 \\
\hline
\end{tabular}

Notes: The $\mathrm{t}$-statistic is in parentheses, and the $\mathrm{p}$ value is in square brackets. $* * *, * *$, and $*$ indicate significance at the 1 , 5 , and $10 \%$ levels, respectively.

\subsubsection{Heterogeneity analysis}

Because of the difference in stock offering price, the influence of investor sentiment on IPO underpricing may also be heterogeneous. Therefore, this paper divides the two classes of stocks with high and low issue prices by the average value and makes empirical estimations, respectively. The results show that although investor sentiment has a significant effect on underpricing in both subsamples, the promoting effect of investor sentiment on underpricing in stocks with lower issue price is less than that in stocks with higher issue price. This paper further explores the heterogeneity of the mechanism and finds that the main reason for the heterogeneity of investor sentiment is that the high investor sentiment in low-priced stocks does not promote the turnover rate as much as that in high-priced stocks. Affected by investment psychology, high-priced stocks will give investors limited room to rise, fearing higher feelings. And penny stocks have limited space to fall, higher space, very popular with retail investors. Many retail investors buy stocks with lower IPO prices, which will increase the volatility of low-priced stocks affected by investor sentiment, which is reflected in turnover rate and price.

TABLE IV. HETEROGENEITY TEST RESULTS OF DIFFERENT ISSUE PRICES

\begin{tabular}{|c|c|c|c|c|c|c|}
\hline VARIABLES & $\begin{array}{l}\text { Ln_up } \\
\text { High_prc }\end{array}$ & $\begin{array}{l}\text { Ln_up } \\
\text { Low_prc }\end{array}$ & $\begin{array}{l}\text { Ln_turn } \\
\text { High_pre }\end{array}$ & $\begin{array}{l}\text { Ln_turn } \\
\text { Low_prc }\end{array}$ & $\begin{array}{l}\text { Ln_up } \\
\text { High_prc }\end{array}$ & $\begin{array}{l}\text { Ln_up } \\
\text { Low_prc }\end{array}$ \\
\hline ln_cicsi & $\begin{array}{l}1.151 * * * \\
(4.54)\end{array}$ & $\begin{array}{l}0.345 \text { **** } \\
(3.50)\end{array}$ & $\begin{array}{l}0.514 * * * \\
(4.92)\end{array}$ & $\begin{array}{l}0.238 * * * \\
(2.87)\end{array}$ & & \\
\hline industryid & $\begin{array}{l}-0.000 \\
(-0.13)\end{array}$ & $\begin{array}{l}0.000 \\
(0.20)\end{array}$ & $\begin{array}{l}-0.000 \\
(-0.18)\end{array}$ & $\begin{array}{l}0.000 \\
(0.07)\end{array}$ & $\begin{array}{l}0.000 \\
(0.03)\end{array}$ & $\begin{array}{l}0.000 \\
(0.09)\end{array}$ \\
\hline ln_lag & $\begin{array}{l}0.426 * * * \\
(4.33)\end{array}$ & $\begin{array}{l}0.017 \\
(0.28)\end{array}$ & $\begin{array}{l}0.120 * * * \\
(3.00)\end{array}$ & $\begin{array}{l}-0.224 * * * \\
(-4.37)\end{array}$ & $\begin{array}{l}0.399 * * * \\
(4.03)\end{array}$ & $\begin{array}{l}0.030 \\
(0.52)\end{array}$ \\
\hline ln_age & $\begin{array}{l}1.689 * * * \\
(5.30)\end{array}$ & $\begin{array}{l}0.603 * * * \\
(2.97)\end{array}$ & $\begin{array}{l}-0.281 * * \\
(-2.22)\end{array}$ & $\begin{array}{l}-0.208 \\
(-1.22)\end{array}$ & $\begin{array}{l}1.972 * * * \\
(6.24)\end{array}$ & $\begin{array}{l}0.843 * * * \\
(4.50)\end{array}$ \\
\hline quantity & $\begin{array}{l}-0.109 * * * \\
(-2.73)\end{array}$ & $\begin{array}{l}-0.142 * * * \\
(-8.60)\end{array}$ & $\begin{array}{l}0.040 * * \\
(2.46)\end{array}$ & $\begin{array}{l}0.000 \\
(0.03)\end{array}$ & $\begin{array}{l}-0.125 * * * \\
(-3.11)\end{array}$ & $\begin{array}{l}-0.139 * * * \\
(-8.64)\end{array}$ \\
\hline ln_pe & $\begin{array}{l}0.407 * * * \\
(4.55)\end{array}$ & $\begin{array}{l}0.834 * * * \\
(15.49)\end{array}$ & $\begin{array}{l}0.114 * * * \\
(3.21)\end{array}$ & $\begin{array}{l}0.229 * * * \\
(5.07)\end{array}$ & $\begin{array}{l}0.470 * * * \\
(5.38)\end{array}$ & $\begin{array}{l}0.798 * * * \\
(15.12)\end{array}$ \\
\hline ln_issueprice & $\begin{array}{l}-0.662 * * * \\
(-7.98)\end{array}$ & $\begin{array}{l}-0.544 * * * \\
(-10.26)\end{array}$ & $\begin{array}{l}-0.019 \\
(-0.56)\end{array}$ & $\begin{array}{l}0.052 \\
(1.17)\end{array}$ & $\begin{array}{l}-0.575 * * * \\
(-7.14)\end{array}$ & $\begin{array}{l}-0.518 * * * \\
(-10.41)\end{array}$ \\
\hline ln_pb & $\begin{array}{l}0.104 \\
(1.15)\end{array}$ & $\begin{array}{l}0.305 * * * \\
(6.42)\end{array}$ & $\begin{array}{l}-0.023 \\
(-0.63)\end{array}$ & $\begin{array}{l}-0.056 \\
(-1.40)\end{array}$ & $\begin{array}{l}0.010 \\
(0.11)\end{array}$ & $\begin{array}{l}0.288 * * * \\
(6.33)\end{array}$ \\
\hline ln_turn & & & & & $\begin{array}{l}0.272 * * * \\
(3.97)\end{array}$ & $\begin{array}{l}0.271 \text { *** } \\
(8.07)\end{array}$ \\
\hline Constant & $\begin{array}{l}-7.732 * * * \\
(-5.89)\end{array}$ & $\begin{array}{l}-3.071 * * * \\
(-4.66)\end{array}$ & $\begin{array}{l}-4.135 * * * \\
(-7.64)\end{array}$ & $\begin{array}{l}-2.125 * * * \\
(-3.83)\end{array}$ & $\begin{array}{l}-3.564 * * * \\
(-3.29)\end{array}$ & $\begin{array}{l}-1.906 * * * \\
(-3.10)\end{array}$ \\
\hline Observations & 1,113 & 1,175 & 1,235 & 1,200 & 1,113 & 1,175 \\
\hline R-squared & 0.145 & 0.524 & 0.061 & 0.063 & 0.141 & 0.544 \\
\hline
\end{tabular}

Notes: The t-statistic is in parentheses, and the $\mathrm{p}$ value is in square brackets. ${ }^{* * *}, * *$, and $*$ indicate significance at the 1 , 5 , and $10 \%$ levels, respectively.

\section{Conclusions}

Existing literatures have studied the relationship between IPO underpricing and investor sentiment in the secondary market. In this paper, the comprehensive index CICSI, which can better measure the investment sentiment in the stock market, is introduced to represent investor sentiment. The proportion of the IPO price lower than the closing price represents the IPO underpricing rate. Based on the perspective of private enterprises listed on GEM in China, this paper takes A total of 2,955 A-share listed stocks from 2003 to 2020 as samples and not only obtains the specific impact of investor sentiment on IPO underpricing through empirical research but also explores the mechanism. The research shows that investor sentiment has a significant promoting effect on IPO underpricing. Investors with optimistic investment sentiment tend to expect the price of IPO stocks to be much higher than the issue price. Thus, increasing the buying demand for IPO stocks prompted changes in the opening and closing prices of the initial offering stocks, thus increasing the underpricing rate of IPO stocks.

The mechanism analysis shows that investor sentiment affects IPO underpricing by influencing the market turnover rate. On the first day of listing, the turnover rate plays a partial intermediary role in the path of investor sentiment affecting IPO underpricing. When investors are 
optimistic about the future price trend of the IPO stock price, their attention to the stock market and their willingness to buy the initial offering stock will increase. Due to the increasing demand of these investors for IPO shares, the trading times increase correspondingly, showing a high turnover rate. The high turnover rate causes the IPO company's stock price to rise sharply on the first day of listing, thus aggravating the IPO underpricing level.

From the perspective of heterogeneity, it is found that investor sentiment plays a smaller role in underpricing than that of high-priced stocks. The reason may be that a large number of retail investors buy low-priced stocks, which leads to increased volatility of low-priced stocks under the influence of investor sentiment.

\section{REFERENCES}

[1] Yunlong Duan, Shuaijie Wang, Weiwei Yang. Journal of Yunnan University of Finance and Economics,2015,31(06):90-101. (in Chinese)

[2] Che-Yahya, Norliza Matsuura, Yoshiyuki Does Individual Investors' Sentiment Explain Japanese IPO Aftermarket Performance?

[3] Pan Shengwen, Wu Chuandong. Journal of Financial Regulation,2020(08):84-101. (in Chinese)

[4] Singla, Harish Kumar, Does ownership structure and market sentiment affect the performance of IPOs in India in short run? A dynamic panel data analysis JOURNAL OF FINANCIAL MANAGEMENT OF PROPERTY AND CONSTRUCTION

[5] Shao Xinjian, He Mingyan, Jiang Ping, Xue Yi, Liao Jingchi. Media Public Relations, Investor Sentiment and Security Issue Pricing [J]. Financial Research,2015(09):190-206.

[6] Chen Yangyang,Goyal Abhinav, Veeraraghavan Madhu,Zolotoy Leon. Terrorist attacks, investor sentiment, and the pricing of initial public offerings[J]. Journal of Corporate Finance,2020,65.
[7] Thomas J. Boulton,Scott B. Smart,Chad J. Zutter. Worldwide short selling regulations and IPO underpricing $[\mathrm{J}]$. Journal of Corporate Finance, 2020,62.

[8] Ren Hui, Sun Qian. An empirical study on the factors influencing IPO underpricing on China's Growth Enterprise Market [J]. Journal of Economics and Management Review,2015,31(06):58-65.

[9] F Cornelli, D Goldreich, Ljungqvist A P. Investor Sentiment and Pre - Issue Market [J]. Forthcoming Journal of Finance, 2004, ( 44 ) : 393 -420.

[10] VERMA R, VERMA P.Noise trading and stock market volatility[J].Journal of multinational financial management, 2007(17):231-243

[11]Robert F. Stambaugh,Jianfeng Yu,Yu Yuan. The short of it: Investor sentiment and anomalies[J]. Journal of Financial Economics,2012,104(2).

[12] Wang,Y.\& X.Xia \& M.Cheng. Empirical Study on Investor Sentiment and IPO Overvaluation[J].Journal of Wuhan University of Technology(Information \& Management Engineering), 200931(5):821-824.

[13] Wen,F.\& J.Xiao \& C.Huang \& X.Cheng. \& X.Yang. The effects of characteristics of investor sentiment on stock price behaviors[J]. Journal of management sciences in China, 2014, 17(3):60-69.

[14] Malcolm Baker, Jeremy C Stein. Market Liquid- ity as a Sentiment Indicator [J]. Journal of Financial Markets, 2004, 7( 3) : 271 - 299.

[15] Malcolm Baker, Jeffrey Wurgler. Investment Sentiment and the Cross - section of Stock Returns[J]. Journal of Finance,2005,( 4) : 1645

[16] Rajan Raughuram , Henri Servaes. Analyst Following of Initial Public Offerings[J]. Journal of Finance,1997,( 52) : 507 - 530. 